\title{
Enhancing Students' Problem Solving Ability through Teaching Material based on Tumpek Wariga as Local Wisdom in Bali
}

\author{
Kadek Sera Harlistya Udayani ${ }^{1}$, Siti Sriyati ${ }^{2}$ \\ \{harlistyaudayani26@gmail.com $\left.{ }^{1}\right\}$ \\ Sekolah Pascasarjana \\ Universitas Pendidikan Indonesia \\ Jl. DR. Setiabudi No.229, Isola, Sukasari, Bandung City, West Java 40154 1,2
}

\begin{abstract}
Teaching materials based on wisdom and local potential are needed in environmental education in order to produce learning resources that are appropriate to students' cultural, geographical and social environment. The purpose of this study was to obtain a picture of the impact or effect of the use of teaching materials based on local wisdom of Tumpek Wariga on achieving students' problem-solving abilities. The method used in this study is a quasi-experiment with a research design that is a non-equivalent pretest-posttest design. The study was conducted at one of the high schools in Denpasar. The research sample consisted of 36 experimental class students who used teaching materials based on local wisdom Tumpek Wariga and 36 control class students who used national teaching materials. Teaching material based on local wisdom Tumpek Wariga has previously been validated by reviewers with results worth using. Data about students' problem-solving abilities are measured by essay questions arranged according to indicators of problem-solving. The research data did not meet the prerequisite test then analyzed through the nonparametric $\neg$ Mann-whitney test. The analysis showed that there were significant differences in posttest results between the control and experimental classes with a significance level of 0.00 . This shows that teaching materials based on local wisdom Tumpek Wariga can improve students' problem-solving abilities.
\end{abstract}

Keywords: Teaching material, Local wisdom, Problem-solving ability

\section{Research background}

One of the biological material taught in schools is the subject of environmental change. This material is taught to high school students in class X. In the 2013 curriculum at the high school level, learning about environmental materials includes 2 basic competencies, namely, Basic Competencies 3.11 and 4.11. Basic Competence 3.11 analyzes data on environmental changes and their causes, and the impact of these changes on life. KD 4.11 is proposing ideas for solving problems of environmental change according to the context of environmental problems in the area. To be able to train students to solve environmental problems in their respective areas, students need to be familiar with the environmental conditions in their area.

Teaching materials or textbooks used by students so far at school are national teaching materials that rarely contain environmental issues in their respective regions. This can make it difficult for students to associate the material obtained at school with the environment they 
encounter in real life. Conversely, learning will be more meaningful if students learn and know directly in real life [1]. Educators need to innovate environmental teaching materials by raising local wisdom contained in their respective regions. Development of teaching materials based on wisdom and local potential will produce learning resources that are appropriate to the culture, geography and local social environment.

The use of teaching materials based on local wisdom is also one way to train students in solving problems. Problem-solving ability is one of the abilities students must-have in the 21 st century. Problem-solving ability is the ability of individuals to effectively solve a problem through knowledge, skills, and actions to reach a solution [2]. The ability to solve problems is not only used in solving environmental problems, but this ability is useful to assist students in solving problems they will face in real life.

The absence of research on the application of reality-based teaching materials and local wisdom of Tumpek Wariga in Bali is encouraging researchers to conduct deeper studies. The application of teaching materials based on local wisdom in Bali is expected to be able to solve students' problem-solving abilities.

\section{Tumpek Wariga Local Wisdom}

Tumpek Wariga is one of the Hindu ceremonies in Bali. Like holidays and other ceremonies, the calculation of holidays or ceremonies in Bali is calculated based on the Balinese calendar which amounts to 210 days. The "Tumpek" ceremony falls when the seven-day cycle ( Saptawara) peaks at Saniscara (Saturday) meets with the peak five-day cycle (Pancawara) Keliwon. The 7-day cycle (Saptawara) in question is the number of days in a week. On the Balinese calendar, the day starts on Sunday ( Redite ), Monday ( Soma ), Tuesday ( Anggara ), Wednesday ( Buda), Thursday ( Wrespati), Friday ( Sukra), Saturday ( Saniscara). The five daily cycles (Pancawara) starts from Umanis, Paing, Pon, Wage, Kliwon.

The Saniscara-Kliwon summit takes place every 35 days. So that within 210 days there are six times Tumpek. The six Tumpek are Tumpek Landep, Tumpek Wariga, Tumpek Kuningan, Tumpek Krulut, Tumpek Kandang and finally Tumpek Wayang. The meaning and purpose of the six types of Tumpek are different, one of which is Tumpek Wariga is a ceremony related to environmental preservation, especially plants. Tumpek Wariga Ceremony is held every 210 days, exactly on Saniscara Kliwon day, Wuku Wariga, 25 days before Galungan [3].

The purpose of this ceremony is as a form of gratitude to God in His manifestation as Sangkara God as ruler or creator of plants [4]. Gratitude goes to Dewa Sangkara for creating various types of plants that are very useful for human survival and asking for plants to grow and flourish so that they can be used during the Galungan holiday. The values of environmental preservation contained in the Wariga Tumpek Ceremony are passed on orally in the implementation of the ceremony.

\section{Problem Solving Ability}

Students need the ability to solve problems to solve the problems at hand. Problem-solving ability is the ability of individuals to effectively solve a problem through their knowledge, skills, and efforts to reach a solution [2]. Problem-solving can be done by involving the ability to acquire and use new knowledge or use old knowledge in new ways. Saygili (2017) adds that the 
problem-solving process involves several skills that are used simultaneously. These skills are understanding the problem, choosing the information needed among the available choices, processing the information obtained and then arranging a solution to solve the problem.

Problem-solving steps proposed by Johnson and Johnson [5] as indicators of students' problem-solving abilities. Indicators of students' problem-solving abilities, namely; (1) formulating the problem, (2) diagnosing the problem, (3) formulating a hypothesis, (4) applying a method of problem-solving, and (5) final evaluation.

\section{The Relationship Of Teaching Materials Based On Local Wisdom With Students' Problem Solving Ability}

Learning in the 21 st century is different from learning in the previous century. Learning in the 20th century does not target high expectations of students, whereas in the 21 st-century education targets high expectations of students through learning. Educators expect and ensure all students can succeed. Education in the 21 st century requires students to have some global awareness and abilities that are aligned with real-life and later working life [6].

One of the global awareness and abilities demanded from 21 st-century education is problem-solving. Preparing human resources who have the ability to solve problems will be more effective if pursued through education. The learning process in class must be adjusted to the expected results. The main principle for teaching students 21 st-century skills is through the use of real-world contexts.

The use of real-world contexts in learning is a key component of 21st-century learning. Students 'experiences in school can be different from students' experiences in life outside of school. Learning activities designed to link student experiences in the real world will focus more on their learning. The use of the real-world context also causes students to be able to see the relationship between the material they are learning in class and the real world is important, so students' learning motivation will increase [6].

Contextual learning can be applied in biology, especially environmental material. Linking environmental subject matter with facts of daily student life is very important to apply. Learning can be achieved if activities in education are centered on authentic tasks or problems, and emphasize a context [7]. Contextual learning can be pursued through the development of teaching materials with local potential. Teaching materials with local potential can help students to develop problem-solving abilities and foster the character of caring for the environment [8]. The presentation of environmental problems expressed in teaching materials is an environmental problem that is close to students. The exposure can also encourage students to be sensitive to the environment and able to develop problem-solving abilities [9].

Learning environments based on local potentials that are oriented toward problem-solving ability and environmental literacy need to be supported by the availability of appropriate teaching materials. The teaching material referred to is teaching material that integrates environmental material with the real conditions of the student's environment and is coupled with local wisdom such as environmental preservation carried out by the surrounding community. The teaching material in question also includes exercises that can support environmental literacy and students' problem-solving abilities. 


\section{Research Method}

This study uses a quasi-experimental method with a research design that is Non-equivalent Pretest-Posttest Design. The population in this study included class X students at one of the state high schools in Denpasar. The sampling technique used was purposive sampling. The considerations used in school selection are; (1) being close to the Tumpek Wariga ceremony, (2) Students studying environmental change material, (3) schools in the city with the most landuse change in Bali, Denpasar City. This study uses two class X in schools that are used for trials. One class to test the implementation of teaching materials in learning while the other class as a control using teaching materials commonly used in schools.

Students' solving abilities are measured using a description test. The description test is used to measure the ability of students in each stage of problem-solving. The problem-solving ability test consists of five questions based on the text of a case. Each question refers to an indicator of problem-solving ability. Indicators of problem-solving ability that are used refer to indications from Johnson \& Johnson [5]. These indicators namely; (1) formulating the problem, (2) diagnosing the problem, (3) formulating hypotheses, (4) determining and determining strategies, (5) evaluation.

Pretest and posttest score analyzes were performed to see the effect of teaching materials on environmental literacy and students' problem-solving abilities. Analysis using SPSS software. The analysis of the data used in this study are:

\section{Prerequisite Test}

The test begins with a prerequisite test in the form of a normality test and a homogeneity test. The normality test aims to determine whether the data distribution is normal or not. The normality test is performed on the average value of pretest and posttest. The normality test used was the Shapiro Wilk test with a significance level $(\alpha) 0.05$. The homogeneity test used is Levene's test with a significance level $(\alpha) 0.05$.

\section{Test different mean}

Two-means test on the pretest and posttest data of the problem-solving ability using the Mann -Whitney test because the prerequisite tests cannot be fulfilled.

\section{Calculation of N-gain ( Normalized gain )}

The results of the pretest and posttest residual problem-solving abilities were analyzed using Normalized gain (N-gain) calculations to see the increase. The formula used is as follows (formula 1) and seen Table 1.

$$
N-\text { gain }=\frac{\text { Spost }- \text { Spre }}{\text { Smaks }- \text { Spre }}
$$

Information :

$N$-gain $=$ Normalized score

Spre $=$ Pretest score

Spost $=$ posttest score 
Smaks $=$ Maximum score of ideas

Table 1 . N-gain Category.

\begin{tabular}{ll}
\hline Index Range & Category \\
\hline$N$-gain $>0.7$ & High \\
$0.3 \leq N$-gain $\leq 0.7$ & Medium \\
$N$-gain $<0.3$ & Low \\
\hline
\end{tabular}

\section{Result}

\subsection{Pretest Data Analysis}

The pretest data analysis of the problem-solving abilities of the control class and experimental students aimed to measure the students' initial problem-solving abilities. Based on the calculation and statistical analysis the following results were obtained.

Table 2. Results of Statistical Analysis of Pretest Data on the Problem Solving Ability of Students in Control and Experiment Classes.

\begin{tabular}{lll}
\hline \multirow{2}{*}{ Component } & \multicolumn{1}{c}{ Pretest } \\
\cline { 2 - 3 } & \multicolumn{1}{c}{ Control } & \multicolumn{1}{c}{ Experiment } \\
\hline The number of students & 36 students & 36 students \\
Average & 60,30 & 59,84 \\
The biggest score & 76,40 & 93,20 \\
The smallest score & 43,00 & 43,00 \\
Normality test & 0,01 & 0,04 \\
Interpretation of normality & Data is not normally distribute \\
Average difference test & 0,92 \\
(Mann-Whitney) & \\
Interpretation of average difference & There is no significant difference average \\
test & score \\
\hline
\end{tabular}

Based on the data in Table 2 the pretest data obtained from the control and experimental class with the same number of students is 36 students. The acquisition of the smallest value in Kela 's control was 43 and the highest value of 69.80 . While in the experimental class the smallest value was 43.00 and the highest value was 93.20. The average value of the control class is 60.30 and the experimental class is 59.84 . The results of the statistical analysis of the pretest data of students' problem-solving ability in Table 2 shows that the control and experimental classes have abnormal data distribution. Because the prerequisite test cannot be fulfilled in both classes, it is continued with a non-parametric test, namely the Mann Whitney- $U$ test. This test was conducted to see whether there were differences in the average value of the environmental 
literacy pretest in the two classes. Results Mann-Whitney $U$ obtained by the Sig. $=0.92$. Because the Sig value $>0.05$, it can be concluded that there is no difference in the average value of the pretest of students' problem-solving abilities in the control and experimental classes.

\subsection{Final Test Data Analysis}

Posttest results from the two classes were then tested for average differences to see whether there was an increase in environmental literacy after being given treatment. The results of the statistical analysis of the posttest score of the problem-solving ability of the control and experimental classes are presented in Table 3.

Table 3 . Statistical Analysis of Posttest Data on Control and Experiment Classes.

\begin{tabular}{lcc}
\hline \multirow{2}{*}{ Component } & \multicolumn{2}{c}{ Posttest } \\
\cline { 2 - 3 } & \multicolumn{1}{c}{ Control } & Experiment \\
\hline The number of students & 36 students & 36 students \\
Average & 75,51 & 88,46 \\
The biggest score & 100 & 100 \\
The smallest score & 46,20 & 69,80 \\
Normality test & 0,51 & 0,02 \\
Interpretation of normality & Data is normally & Data is not normally \\
& distributed & distributed \\
Average difference test & 0,00 & \\
(Mann-Whitney) & \multicolumn{2}{c}{} \\
Interpretation of average difference & $(0,00<0,05)$ & \\
test & There is a significant difference average \\
& score & \\
\hline
\end{tabular}

Based on the data in Table 3 the data posttest values obtained smallest in the control class are 46.20 and the highest score of 100. While the experimental class obtaining the smallest value is 69.80 and a high of 100 . The average value of the control class is 75,51 and experimental class 88.46. Although the highest score in the two classes is the same, that is 100 , when seen in the acquisition of the average experimental class is higher than the control class. $\mathrm{H}$ acyl statistical analysis of data posttest problem-solving ability of students in Table 3 shows that the control class has a normal distribution of data and experiments while in class is not normal. Because the pre-requisite test cannot be fulfilled, it is continued with the Mann-Whitney nonparametric test. Based on the results of the Mann Whitney test the Sig. $=0.00$. Because of the Sig value $<0.05$, it can be concluded that there are differences in the average value of the problem-solving abilities of the control and experimental class students. In other words, environmental teaching materials in Bali based on Tumpek Wariga's local wisdom can improve students' problem-solving abilities.

\subsection{Improved Students' Problem Solving Ability}


The $\mathrm{N}$-gain values obtained from each student in both classes are grouped according to the improvement categories. A comparison of distributions in each category of $\mathrm{N}$-gain improvement in control class and experimental solving ability is presented in Figure 1.



Fig. 1. Comparison of Student Problem Solving Ability Improvement Categories.

The improvement of problem-solving ability is divided into three categories namely high, medium and low. In Figure 1, there are no students in the control class who have increased in the high category. Dominant control class students experienced an increase in the medium and low categories. Control class students who experienced an increase in the moderate category amounted to $58.33 \%$ and a low increase of $41.67 \%$. Students in the dominant experimental class experienced increased problem-solving abilities in the high and medium categories. Experimental class students experienced an increase in the high category by $55.55 \%, 58.33 \%$ in the medium category and $5.55 \%$ in the low category.

There are no control class students who have increased problem-solving abilities in the high category allegedly because the teaching material used does not contain question exercises in accordance with the steps of problem-solving. Meanwhile, the number of experimental class students who have increased problem-solving skills in the high category due to the problemsolving exercises contained in teaching materials. Teaching materials used in the experimental group also contained environmental facts in Bali and the local wisdom of Tumpek Wariga.

\section{Decision}

The results of the Man-Whitney test on the posttest data showed that the ability of the students in the control and experiment classes differed significantly. In other words, the use of environmental teaching materials in Bali based on local wisdom Tumpek Wariga can improve students' problem-solving abilities. The difference in the problem-solving abilities of the experimental and control class students is thought to be due to several things, namely: 1) the existence of problem-solving exercises contained in teaching materials 2 ) environmental facts 
in Bali contained in teaching materials, 3) the values of local wisdom Tumpek Wariga in teaching materials.

The improvement of the problem-solving skills of the experimental class students was obtained from the results of the practice of environmental literacy questions contained in the teaching material. The questions contained in teaching materials are questions related to environmental facts in Bali based on local wisdom. The questions contained in the material are arranged in accordance with the steps of solving the problem. The existence of the practice questions aims to train students on how to solve problems. In the teaching material used in this study, there are 4 exercises about problem-solving. In the first question, exercise students are still very lacking in doing problem-solving exercises. The question exercises given routinely cause students to experience a significant increase in problem-solving. The results of this study are in line with the results of research conducted [10] that teaching materials on the preservation of the slopes of Mount Sindoro Sumbing based on local wisdom can significantly improve students' problem-solving abilities. Searching information to answer practice questions through books (second-hand information) is one way to train students to get problem-solving [8].

The environmental facts contained in the teaching material also help students in the experimental class achieve maximum problem-solving skills. Students can link the concepts and environmental facts they get so they can determine the right strategy to solve environmental problems. The use of environmental problems is not only good for science learning, but also for solving problems in students' daily lives. Problem-based learning can train students to formulate problems, form hypotheses, and evaluate problem-solving processes so as to improve students' thinking abilities [11].

Local wisdom Tumpek Warig is one of the local wisdom of plant preservation in Bali. The integration of these local wisdom values into teaching materials equips students with ways to solve the problems they face in the current environmental conditions. As an example of environmental problems that are currently and will be faced by the environment in Bali is the conversion of the function of green land for the tourism and development sector. Equipping students with the values of local wisdom Tumpek Wariga can help students as young people to face the challenges of environmental problems today and in the future.

\section{Conclusion}

The results of the implementation of teaching materials containing local wisdom Tumpek Wariga in schools indicate that there is a significant difference between the average value of the posttest problem-solving abilities of experimental class students who use local wisdom-based teaching materials with control classes that use national teaching materials.

\section{References}

[1] Gunawan, A., Hariyono., Ari, S.: Perbedaan Hasil Belajar dengan Pendekatan Kontekstual berbasis Budaya Lokal di Madura. Jurnal Pendidikan, 2 (6), pp. 867-873 (2017)

[2] OECD.: PISA 2015 Collaborative Problem-Solving Framework. Paris: OECD (2017)

[3] Payuyasa, I.N.: Tumpek Uduh, Kearifan Lokal Bali untuk Meningkatkan Mutu Pendidikan Karakter. Jurnal Penjaminan Mutu, 3 (2), pp. 206-214 (2017) 
[4] Narottama, N., Suarja, I.K., Lestari, D.: Tumpek Wariga as an Ecology based Local Genius in Supporting Sustainable Tourism. International of Applied Science in Tourism and Events, 1, (1), pp. 49-61 (2017)

[5] Sanjaya. W.: Strategi Pembelajaran Berorientasi Standar Proses Pendidikan. Kencana: Bandung (2010)

[6] Zubaidah, S.: "Keterampilan Abad Ke-21: Keterampilan yang Diajarkan melalui Pembelajaran". Prosiding Seminar Nasional Pendidikan STKIP Persada Khatulistiwa Sintang pp. 1-17 (2016)

[7] Kamaludin, S., Hertien, K.S., Wahyu, S.: Developing Issue-based Teaching Materials to Improve Student Learning Outcomess in Freswater Biology Course. Indonesian Journal of Biology Education, pp. 161-170 (2017)

[8] Tivani, I., Paidi.: Pengembangan LKS Biologi Berbasis Masalah untuk Meningkatkan Kemampuan Pemeahan Masalah dan Karakter Peduli Lingkungan. Jurnal Inovasi Pendidikan IPA, pp. 35-45 (2016) [9] Setyowati, T.D.: Penerapan Bahan Ajar Bermuatan Lokal Keanekaragaman Hayati di Kawasan Taman Nasional Teesso Nilo untuk Meningkatkan Keterampilan Pemecahan Masalah Siswa Kelas X SMA. (Tesis). Sekolah Pasca Sarjana, Universitas Pendidikan Indonesia, Bandung, (2018)

[10] Mannan, N.M.: Pengembangan Bahan Ajar Ipa Terpadu Tipe Webbed Tema Pelestarian Lereng Gunung Sindoro-Sumbing Berbasis Kearifan Lokal Untuk Menggali Kemampuan Pemecahan Masalah Siswa Kelas VII. (Tesis). Sekolah Pascasarjana. Universitas Pendidikan Indonesia, (2016)

[11] Rosnanda, D., Sarwanto, S., Nonoh, S.A.: Pengembangan Modul Pembelajaran Berbasis [12]Masalah Pada Materi Litosfer Untuk Meningkatkan Keterampilan Berpikir Kritis Siswa SMP. Jurnal Pendidikan IPA, pp. 141-152 (2017) 